Mawa'izh

Jurnal Dakwah dan Pengembangan Sosial Kemanusiaan

Vol. 9, no. 2 (2018), pp. 200-223.

DOI: https://doi.org/10.32923/maw.v9i2.785

\title{
Pemikiran dan Gerakan Dakwah KH. Dja'far Addari
}

\section{Rusydi Sulaiman}

IAIN Syaikh Abdurrahman Siddik Bangka Belitung, Indonesia

abirusydi@yahoo.co.id

\section{Amir Syuhada}

IAIN Syaikh Abdurrahman Siddik Bangka Belitung, Indonesia

\begin{abstract}
The existence of Islam and its varieties among society indicates a big contribution of some scholars including Moslem scholars in Indonesia. KH. Dja'far Addari was one of the pioneers in Bangka who could prove it.- had a big role in changing civilization. Beside idealism and strong struggle, his charisma plays a big role. Dja'far Addari was not only muballigh (conventional Islamic preacher), but productive writer. He travelled far for seek of knowledge (from Bangka Selatan to Mecca) when he was 14 years old under the supervision of salaf Moslem scholars, then went home to his motherland. This article focusses on the thought of Dja'far Addari which consist of Tauhid, syari'ah and Akhlak, then his social movement as Dakwah Islam. Many key persons have been interviewed in searching detail sources in this research. The existence of this Guru implicates some influences, such as: adat istiadat and local tradition, system of belief, strengthening economy and entrepreneurship. The figurism of Dja'far Addari inspires new civilization in Bangka Selatan; Dallas, Airgegas even Pangkalpinang.
\end{abstract}

Keywords; Dja'far Addari, thought, movement, dakwah

\begin{abstract}
Abstrak: eksistensi Islam dan beraga variannya di masyarakat mengindikasikan kontribusi yang besar beberapa cendekiawan termasuk cendekiawan muslim di Indonesia. KH. Dja'far Addari merupakan salah satu perintis di Bangka mempunyai peranan besar dalam merubah peradaban. Selain idealism dan perjuangan yang gigih, karisma beliau memainkan peran besar. Dja'far Addari tidak hanya seorang muballigh, melainkan seorang penulis yang produktif. Beliau bepergian jauh untuk mencari ilmu pengetahuan (dari Bangka sampai Mekkah) ketika beliau berusia 14 tahun di bawah bimbingan cendekiawan salaf, kemudian kembali ke tanah airnya. Artikel ini memfokuskan diri pada pemikiran Dja'far Addari yang terdiri dari tauhid, syari'ah, dan akhlak yang direalisasikan dalam gerakan sosial sebagai Dakwah Islam. Banyak tokoh kunci yang diwawancarai untuk mencari sumber detail dalam penelitian ini. Keberadaan Guru memberikan beberapa pengaruh, seperti: adat istiadat dan tradisi lokal, sistem kepercayaan, penguatan ekonomi dan kewirausahaan. Figurisme Dja'far Addari menginspirasi peradaban baru di Bangka Selatan; Dallas, Airgegas, bahkan Pangkalpinang.
\end{abstract}

Received: 05-10-2018; accepted: 05-11-2018; published: 05-12-2018 


\section{A. Pendahuluan}

I slamisasi dan intensifikasi Islam di Indonesia berlangsung cukup lama kemudian memberi sentuhan peradaban tersendiri terhadap kehidupan sosial masyarakatnya. Situasi tersebut memberikan kesimpulan bahwa begitu besar kontribusi tokoh dan ulama tertentu di negeri ini, baik kiprah maupun pemikiran mereka. Periode abad ke-19 dan 20 Masehi merupakan periode sejarah yang sangat bermakna bagi Islam di Indonesia, ditandai dengan munculnya gerakan dan organisasi sebagai pembaharu peradaban.

Saat itu, Barat dengan masa Renaissance mengambil dasar modernisasi dan rasionalisasi pada segala aspek kehidupan. Perkembangan pemikiran pada akhirnya membangun struktur masyarakat baru walaupun harus ditebus dengan banyak kehancuran materi. Kelahiran baru memang seringkali menimbulkan "menyingkirkan" generasi lama. ${ }^{1}$ Namun demikian, tidak semuanya (tokoh dan ulama) bergeser-tetap mempertahankan otoritas keagamaan dan prinsip pemikirannya. Di tengah menguatnya gejolak sosial dan politik, basis tradisionalisme masih mampu bertahan sambil juga bersikap akomodatif terhadap beberapa pembaharuan modern. Pada dasarnya pola yang dilakukan para ulama dalam mendekati masyarakat dalam rangka menyebarkan pemikirannya sama dengan dakwah para wali dahulu kala di Pulau Jawa. Walaupun memang tidak dapat dikatakan semua yang ada demikian (tidak dapat digeneralisasi), namun kebanyakan kasus hal itu terjadi. ${ }^{2}$

Diantara ulama tradisional awal Islam di Indonesia yang fokus pada pemikiran keislaman dan memiliki beberapa karya tulis antara lain adalah: Nawawi al-Bantani, Kholil Bangkalani, Ahmad Dahlan, Hasyim Asy'ari, At-Tirmisi, Hamzah Fansuri, AsSingkili, Muhammad Arsyad Al-Banjari, Abdussomad al-Palembangi, Khotib alMinangkabawi. Tokoh-tokoh tersebut menginspirasi kemunculan ulama-ulama baru di Indonesia, baik yang tradisional maupun modern. Bahkan terbentuk dan juga berkembangnya lembaga-lembaga pendidikan seperti pondok pesantren, madrasah dan sentra-sentra belajar lain terinspirasi oleh corak pemikiran ulama-ulama tersebut. Pendekatan dakwah yang dilakukan pada akhirnya membuktikan bahwa ide-ide mereka dapat diterima di tengah masyarakat.

\footnotetext{
${ }^{1}$ Saifa Auliya Achidsti, Kyai dan Pembangunan Institusi Sosial, (Yogyakarta: Pustaka Pelajar, 2015), p. Ix.

${ }^{2}$ Ibid., pp. 82-83.
} 
Situasi tersebut juga memberi sentuhan tersendiri terhadap pulau Bangka sehingga lahirlah beberapa ulama di pulau tersebut yang dipandang memiliki pemikiran dan keberadaan diri mereka sangat berpengaruh di kalangan masyarakat. KH. Ja'far Addari-selanjutnya disebut Ja'far Addari adalah tokoh yang merupakan representasi kelompok tradisional dan kemudian lakukan pembaharuan di wilayah Bangka Selatan. Begitu besar pengorbanan dan kontribusi pemikiran mereka bagi masyarakatnya. Bayangkan bila proses islamisasi dan intensifikasi Islam tidak sempat terjadi di Pulau Bangka yang dulunya sangat rawan, pasti penduduk setempat tidak mengenal agama dan peradaban mereka tidak sebaik saat ini. Keyakinan animisme dan dinamisme sudah bercokol cukup lama dan selanjutnya mengakar-menemukan basisnya di pulau tersebut.

Ja'far Addari adalah ulama yang memenuhi kualifikasi dan pembaharu cepat dalam konteks perubahan peradaban di Bangka. Bila disebutkan beberapa putra Bangka yang telah menetap lama,"naon" pada awal abad ke- 20 Masehi di Mekkah, maka Ja'far Addari adalah satu ulama yang berasal dari Bangka Selatan yang tekun mendalami agama Islam di tanah suci tersebut. Dari Desa Delas kemudian melakukan dakwah Islam di Airgegas. Telah terjadi pembaharuan peradaban-purifikasi terhadap ajaran Islam dengan kehadiran tokoh kharismatik tersebut. Praktik keagamaan, tradisi dan adat istiadat yang sebelumnya kental dengan keyakinan lama (urang lom) kemudian bergeser dan mengalami perubahan yang berarti menjadi urang lah-lah besunat (sudah berkhitan) atau sudah beragama Islam.

Perubahan sosial masyarakat di sebagian wilayah di pulau Bangka mulai terasa dengan kehadiran tokoh tersebut. Kedalaman pemikiran keislaman Ja'far Addari mampu merubah situasi masyarakat dari pengaruh lama menjadi lebih baik. Perubahan peradaban tersebut sangat dirasakan masyarakat; terkikisnya praktek animisme dan dinamisme yang sebelumnya sangat mengakar, tingginya sikap antusias keagamaan dan intensnya pengamalan ajaran Islam. Hal hal yang sebenarnya agak mustahil tersentuh apalagi berubah, kenyataannya memang berubah bahkan terhapus sama sekali berkat kehadiran Ja'far ADDARI di Air Gegas dan sekitarnya. Dengan kelebihan tertentu yang melekat pada diri Ja'far ADDARI, sang guru mampu membalik apa-apa yang diragukan masyarakat sebelumnya. Apresiasi dan ketundukan mereka pun mengalir kepadanya, 
dan bahkan pasca kematiannya nuansa kebesaran sang guru hingga saat ini masih dirasakan.

Ketokohan Ja'far Addari memberikan sentuhan tersendiri bagi tokoh-tokoh berikutnya untuk lakukan perubahan keislaman. Selain nuansa kepribadiannya, ia juga menulis beberapa kitab dasar tentang agama Islam; Kitab Sabilul Muttaqin (ilmu fiqh), Kitab Nurul Yaqien fii Ushuluddin (ilmu tauhid), Kitab Nikah dan Kitab Tashawwuf. Penguasaan teoritik keislaman tersebut kemudian diamalkan kepada komunitas setempat. Artinya Ja'far Addari adalah ulama pemikir dan juga pelaku dakwah Islam yang memperbaiki peradaban masyarakat.

Bila terkhusus tentang Islam di Bangka dan yang terkait, maka sangat sedikit ditemukan literatur berupa buku apalagi hasil penelitian. Kenyataannya hingga saat ini belum ada ghirah ilmiah akademisi dan para intelektual muslim terhadap ketokohan KH.Ja'far ADDARI, tidak juga tokoh-tokoh semacamnya. Hal tersebut kemudian menjadi dasar bagi peneliti untuk mengelaborasi lebih jauh tentang ketokohan ulama tersebut. Sekali lagi, Ja'far ADDARI adalah ulama di Bangka Selatan yang mengawali tradisi "Noan" di Mekkah dan kemudian lakukan pembaharuan keislaman pasca studinya belasan tahun di tanah suci tersebut.

Berdasarkan penelusuran penulis tentang sosok Ja'far ADDARI dan kekuatan pengaruhnya terhadap perubahan sosial di Bangka, maka tulisan ini dilakukan secara spesifik membahas tentang latar belakang sosial KH Ja'far ADDARI, ketokohan, konsep pemikiran dan gerakan dakwahnya di Pulau Bangka. Sudah pasti kemunculan guru tersebut dengan segala kelebihan dan juga kekurangan semasa hidupnya, memberikan pengaruh positif bagi generasi berikutnya.

\section{B. Pembahasan}

Pemikiran seseorang pada umumnya diwarnai oleh riwayat hidup, pendidikan, lingkungan dan status sosialnya. Perjalanan hidup yang dijalani dan pendidikan yang ditempuh serta persentuhannya dengan lingkungan akan memberikan pengaruh tersendiri terhadap bentukan pemikiran. Begitu pula seorang tokoh atau ulama tertentu dengan status sosial dan kebesaran serta kepribadian dirinya sudah pasti memberikan pengaruh yang baik terhadap masyarakat sekitarnya. 


\section{Riwayat Hidup Singkat}

Sebagaimana anak umumnya Ja'far kecil juga didik dan dibesarkan dengan penuh kecintaan oleh kedua orangtuanya. Ja'far-selanjutnya disebut Ja'far ADDARI bin H. Muhammad lahir pada 2 Juni 1911 di Desa Delas dan wafat tgl 27 Nopember 1994 di Semabung Kota Pangkalpinang dari pasangan; seorang ayah bernama H. Muhammad dan seorang ibu bernama Hj. Husnah. ${ }^{3}$ Ja'far merupakan anak keempat dari 4 bersaudara, yaitu H. Soleh bin H. Muhammad, Hj. Nafsiah binti H. Muhammad, dan Ismail bin H. Muhammad.

Selanjutnya Ja'far menginjak usia dewasa dan menikah. Kekuatan ke tokohan dan kepribadiannya mengundang simpati para perempuan saat itu, dan dalam rangka penyebaran dakwah Islam di tengah masyarakat, Ja'far ADDARI menikahi tiga perempuan selama hayatnya, yaitu: pertama, Hj. Aminah, dikaruniai seorang anak bernama Gusti; kedua, Hj. Misna binti H. Zainuddin, juga dikaruniai seorang anak, bernama Hj. Aini; ketiga adalah Hj. Zahra asal Pangkalpinang dengan seorang anak bernama Hj. Kartini.

Berbeda dengan kondisi keluarga umumnya di Bangka Selatan, Ja'far termasuk anak yang terlahir dari keluarga yang sangat agamis. Didikan kedua orangtua dalam bidang ilmu agama menjadi pijakanbagi Ja'far untuk tetap semangat dalam belajar. Ketekunan dalam belajar agama sejak kecil membedakan Ja'far dari anak-anak seusianya. Selain bimbingan orangtua di rumah dan pembelajaran Al-Qur'an dan tajwid serta praktik ibadah sehari-hari, Ja'far kecil belajar ilmu agama dibawah bimbingan para guru ngaji di desa bersama anak-anak sepantaran.

Bila dilihat dari kondisi sosial politik dan keagamaan di Delas saat itu agak mustahil bagi para remaja untuk menempuh pendidikan agama di luar pulau. Namun tidak demikian berlaku bagi seorang Ja'far. Pengaruh didikan guru dan bimbingan orang tua di kampung kecil memberi motivasitersendiri baginya untuk belajar mendalami agama. Siapa kemudian yang menginspirasi dirinya sehingga tergerak untuk studi keluar pulau, karena saat itu ia masih sangat remaja. Usia remaja adalah waktunya bermain, dan sedikit sekali yang fokus apalagi menekuni sebuah disiplin ilmu tertentu.

Tepatnya, tahun 1925 dan ketika usianya menginjak 14 tahun, ia berangkat ke tanah suci untuk menuntut ilmu agama di Madrasah Darul Ulum Mekkah.13 tahun

${ }^{3}$ Rusydi Sulaiman, KH.Ja'far AD-DARi dan Semangat Peradaban, Kata Pengantar dalam Kitab Fiqh Ja'far AD-DARI, terjemahan Amir Syuhada dari Kitab Sabilul Mutaqien, (Jakarta: Pustaka Pahema, 2016),h.vii 
menempuh pendidikan di Darul Ulum (dari tahun 1925 sampai dengan 1938)bukan waktu singkat dalam belajar ilmu agama. Tidak sedikit tentunya disiplin ilmu yang didalami sehingga meraih tingkat akademik ADDARI-istilah yang dinisbatkan ke lulusan Perguruan Darul Ulum. Teman-teman seperjuangannya yang berasal dari Bangka ketika itu antara lain adalah KH. Abdullah ADDARI (Pulau Besar), KH. Mukhtar ADDARI (Pangkalpinang), KH. Muhammad ADDARI(Baturusa), KH. Usman Gofar ADDARI (Kemuja). Darul Ulum saat itu sudah menerapkan sistem klasikal dalam proses pembelajarannya, maka kemunculan beberapa sekolah Arab dan madrasah di Pulau Bangka hampir pasti terinspirasi pembentukannya dari pengalaman pendidikan model tersebut.

Setelah naon (menetap) di Mekkah dalam rangka menuntut ilmu, Ja'far pulang ke kampung halaman di Bangka untuk mengamalkan dan mengajarkan ilmu yang telah diperoleh selama bertahun-tahun didalaminya. Desa Delas adalah titik awal dakwahnya, kemudian pindah ke Airgegas karena alasan tertentu, dan menetap lama di desa tersebut sebelum akhirnya eksodus ke Pangkalpinang (1950-an sampai 1966). ${ }^{4}$ Suasana Airgegas membuatnya tertarik untuk berjuang-berdakwah secara lisan dan tulisan. Di desa tersebut, ia menulis beberapa buku tentang ilmu-ilmu dalam Agama Islam, seperti Fiqih, Tauhid dan Akhlak dengan menggunakan bahasa Arab Melayu dan metode Tanya jawab-beberapa karya yang sangat bermanfaat bagi keberlangsungan pemahaman Islam di kalangan masyarakat sesudahnya.

Selain seorang da'i, KH. Ja'far ADDARI pernah mengabdi sebagai petugas Kantor Urusan Agama di Kecamatan Payung. Namun disayangkan, jabatan tersebut dilepaskannya, karena ia ingin menekuni bidang dakwahnya. Disamping berdakwah, kyai juga menekuni bidang pertanian dan perdagangan. Dengan situasi tersebut, dakwah Islam dapat ditopang dengan kekuatan dana yang bersumber dari dua aspek tersebut. Kekayaan tidak lalu menghalanginya untuk terus berdakwah di tengah masyarakat. Saat menetap di Airgegas, sang guru dikenal sangat kaya; memiliki beberapa truk dan mobil, beberapa lahan kebun karet dan ladang ume di desa-desa sekitar serta toko. Di saat harus mengisi pengajian atau ceramah di desa-desa jauh, cukup banyak murid dan masyarakat yang menyertainya. Semuanya diangkut menggunakan beberapa kendaraan miliknya tersebut.

${ }^{4}$ Wawancara dengan Ust.Abdus Shomad di kediamannya Desa Airgegas Bangka Selatan, tgl. 21 Mei 
KH Ja'far ADDARI selalu mengeluarkan bahan bakar dan konsumsi untuk setiap kegiatan pengajian tersebut. ${ }^{5}$ Sebagai seorang da'i yang kompeten dan digemari masyarakat, sang guru mengajar ilmu agama di berbagai majlis dan forum pengajian. Tidak sedikit masyarakat yang mendalami ajarannya sehingga berturut-turut mengundangnya. Jumlah santri pun bertambah. Diantara para murid yang tersisa dan intens mengajarkan ilmuilmu yang telah dokntribusi oleh kyai kharismatik tersebut selama berada di Airgegas adalah: Abdus Shomad, H.Romlan, H. Muhammad Nur, H.Erwin, Safirin, Sanik. Hingga saat ini pengajian kitab-kitab karyanya masih berjalan di majlis-majlis di tengah masyarakat. ${ }^{6}$

\section{Kepribadian dan Ketokohan KH. Ja'far ADDARI}

Ketika seseorang dianggap ketokohannya oleh masyarakat tertentu, maka sudah pasti ada aspek-aspek tertentu dalam dirinya yang menggugah orang lain, apakah itu kepribadian, kompetensi diri, kharisma atau kelebihan-kelebihan lainnya. Sekilas bisa dibuat-buat oleh orang tertentu, namun sesungguhnya tidak. Aspek-aspek internal dalam dirilah yang kemudian dirasa memiliki kekuatan tertentu sehingga memberi daya tarik tersendiri. Kyai misalnya adalah sosok yang disegani karena sikap rendah hati (tawadhu'), kedalaman ilmunya, kharisma, sikap bijak dalam menyikapi sesuatu keadaan atau mungkin faktor keturunan. Menurut Zamakhsyari Dhofier, disebut kyai bila seseorang mengasuh sebuah pondok pesantren walaupun tidak menutup kemungkinan tokoh yang tidak memiliki pesantren tetap dapatdisebut kyai tergantung bagaimana karakter dan faktor sosialnya masing-masing. ${ }^{7}$

Bila disebutkan bahwa salah satu sifat baik seorang ulama adalah rendah hati atau tawadhu', KH. Ja'far ADDARI atau guru Ja'far merupakan sosok yang tawaddu'. Dengan bekal ilmu agama yang mumpuni, tokoh tersebut tidak serta merta merasa lebih dari orang lain. Bertambah tinggi ilmu seseorang biasanya ia bertambah merunduk bagaikan padi yang sudah masak. Dan dengan bekal cukup harta bahkan berlimpah diatas ratarata penduduk ketika itu, ia juga tidak menjaga jarak dengan masyarakat. Sifat tersebut membuat masyarakat menjadi kagum terhadap dirinya. Akhirnya masyarakat yang

\footnotetext{
${ }^{5}$ Wawancara dengan H.Romlan di kediaman Ust..Abdus Shomad, Desa Air Gegas Bangka Selatan,
} $\operatorname{tgl} 21$ Mei 2017

${ }^{6}$ Sulaiman, KH.Ja'far AD-DARI.,h.viii 1982)

7 Zamakhsyari Dhofier, Tradisi Pesantren: Studi tentang Pandangan Hidup Kyai,(Jakarta: LP3ES, 
Mawa'izh

Jurnal Dakwah dan Pengembangan Sosial Kemanusiaan

Vol. 9, no. 2 (2018), pp. 18-25.

mengenalnya tidak canggung atau segan berkomunikasi dengannya. Walaupun ia seorang guru atau kyai yang disegani banyak orang, murid-muridnya diberi keleluasaan bertanya tentang banyak hal saat belajar menimba ilmu agama. Kyai tidak membatasi waktu untuk bertanya tentang apapun kepadanya. ${ }^{8}$

Ia dikenal sebagai sosok tokoh yang tidak tebang pilih atau pilih kasih kepada orang, siapapun dia dan darimana asal usulnya. Semaunya diberlakukan sama dan disikapi dengan sebaik-baiknya. Jika ada tamu yang datang baik penuntut ilmu maupun penyebar ilmu (da'i) selalu beliau perlakukan dengan baik. Dalam keseharian, kyai selalu menjaga hubungan dengan manusia secara baik, baik terhadap kelompok masyarakat yang mengharapkan kehadiran beliau maupun kepada masyarakat yang tidak mengharapkannya. Tidak ada kebencian terhadap orang lain sudah tertanam dalam dirinya. Kyai tetaplah kyai, ia diposisikan sebagai tokoh yang berada diatas daripada masyarakat biasa/ kebanyakan. Mungkin kyai dipandang oleh masyarakat sekitar dengan dimilikinya beberapa kelebihan yang melekat. ${ }^{9}$

Sikap sederhana selalu terpancar dari diri sang kyai dan terkejewantahkan dalam keseharian hidupnya berupa ucapan, tingkah laku dan perbuatan serta penampilannya. Tidak pernah berlebihan dalam bertindak meskipun ia memiliki hak untuk melakukannya. ${ }^{10}$ Kesederhanaan yang dilakoni secara istiqomah memudahkannya dalam menikmati setiap detik langkah kehidupannya. Sikap ini juga membuat orang lain tidak menjaga jarak dengannya. Ia nampak santai, selalu senyum dan ucapkan salam kepada siapapun yang ditemuinya. Menyapa orang lain sudah menjadi kebiasaannya di tengah masyarakat. Begitu sikap dan kepribadiannya sangat mengagumkan orang-orang disekitarnya, apalagi secara simbolik ia juga tidak berjubah layaknya kyai-kyai besar di daerah tertentu di Indonesia.

Berbekal ilmu agama yang memadai, sang guru memiliki prinsip keagamaan yang kuat, mestinya bersikap tegas terhadap situasi keagamaan tertentu. Kenyataannya tidak demikian, ia bersikap lemah lembut terhadap perilaku masyarakat yang melenceng dari syariat Allah swt. ${ }^{11}$

\footnotetext{
11 Wawancara dengan Ust.Abdus Shomad di kediamannya di Desa Airgegas Bangka Selatan, tgl. 22 Juli 2017
}

8 Wawancara dengan H. Naiz di kediamannya di Desa Airgegas Bangka Selatan, , tgl. 22 Mei 2017

${ }^{9}$ Auliya Achidati, Kyai dan,h. 30

2017

10 Wawancara dengan H. Erwin di kediamannya di Desa Airgegas Bangka Selatan, , tgl 27 Mei 
Kefaqihan KH Ja'far ADDARI dalam bidang ilmu agama Islam menggugah masyarakat sehingga semakin memiliki ghirah ilmiah untuk memahami Islam secara kaffah. Terlebih penggunaan metode langsung atau tallaqqi sangat sesuai dengan kondisi masyarakat ketika itu. Satu hal lain yang menjadi tarik bagi masyarakat adalah perangai baik dan pembawaan dirinya yang sangat sabar serta mengayomi jama'ah yang datang. Siapapun saat itu pasti tertarik dan selalu ingin belajar mendalami agama.

KH. Ja'far merupakan sosok da'i ideal di Bangka Selatan, utamanya wilayah kecamatan Airgegas ketika itu. Ia sangat komunikatif dalam berdakwah. Gaya bahasanya selaras dengan lisan masyarakat. Materi dakwahnya sangat sederhana dan mengenadengan budaya lokal, dan logika berpikir juga sejalur dengan alur pikir masyarakat. Berkat intensitas dan istiqomah dalam menjaga hubungan dengan masyarakat (habluminnas), KH Ja'far ADDARI menjadi rujukan bagi masyarakat dalam menyelesaikan banyak persoalan. Praktik-praktek yang sudah sangat mentradisi dan bertolak belakang dengan syari'ah Islam, seperti Bayar niat, Hikok helawang, Sedekah bumi, dan hal-hal lain yang terkaitlambat laun juga terkikis habis bak ditelan bumi.

Dalam menyelesaikan permasalahan, sang guru sangat jeli dan sangat mengetahui akar permasalahan atau sebab permasalahan itu terjadi. Masalah apapun dapat dihadapi dan dicarikan solusinya. dengan bijak. Ketika hendak menghentikan ritual Hikok Helawang di Airgegas, beliau mendalami apa itu Hikok Helawang dengan mengikuti ritual ini selama 4 tahun lamanya. Setelah benar-benar memahami dengan pasti dan yakin akan adanya unsur yang tidak baik dalam kegiatan tersebut, barulah ia memahamkannya sedikit demi sedikit kepada masyarakat. Bila sudah pasti kekeliruan, ia memberanikan diri untuk menghentikan ritual tersebut meskipun masih ada yang tidak setuju dengan keputusan tersebut. Satu hal yang cukup menguatkan akidah masyarakat bahwa dalam penutupan ritual Hikok Helawang, kyai berani menghadapi mereka yang menentangsikapnya. Ia pun siap bertanggungjawab atas adanya penyakit atau kematian menimpa masyarakat pasca penutupan tradisi tersebut selama dua tahun. Hal tersebut kenyataannya tidak terjadi seperti yang dikhawatirkan penduduk Aurgegas selama ini. Pengikut bertambah yakin akan model dakwah yang dilakukan oleh KH Ja'far ADDARI.

Kecerdasan Kyai tersebut dalam berdakwah juga bisa dilihat dari materi dakwah yang lugas, padat dan tepat serta sesuai dengan kebutuhan masyarakat, seperti materi baca al-Quran, tauhid (akidah) dan Syariah yang mencakup shalat, zakat, puasa, haji, 
pengurusan jenazah, muamalah dan ibadah dan doa sehari-hari yang ma'tsur (dari Rasulullah saw). Untuk menguatkan pemahaman tentang ilmu-ilmu tersebut, kyai selalu membaca buku di selang waktu yang ada bahkan ketika menjaga toko daganganmya. Bila tidak ada pembeli beliau sempatkan untuk membaca buku. Dengan modal bahasa Arab yang fashih beliau langsung mengkaji ilmu-ilmu keislaman dari sumber-sumber asli dan mu'tamad dan mautsuq (terpercaya).

Dalam berdakwah, KH Ja'far ADDARI termasuk dalam kategori pendakwah yang tangguh dan energik. Selain memberikan pengajian di rumah dan masjid Airgegas, kyai juga berdakwah keliling kampong-memberikan ceramah pada hari besar Islam. Kegiatan dakwah keliling selanjutnya merambah ke perkotaan. Dua masjid di Pangkalpinang yang kerap digunakan untuk pengajian adalah masjid Jami' Pangkalpinang dan masjid at-Taqwa Semabung. ${ }^{22} J a r a k$ dan waktu bukan penghalang baginya dalam berdakwah, maka tak heran jika banyak tokoh masyarakat dan tokoh agama yang menghormatinya. Melalui ta'lim ini jaringan dan jalinan silaturrahim beliau semakin luas dan semakin dikenal oleh masyarakat Bangka secara umum. Saat itu hampir tidak ada orang yang tidak mengenal Ja'farADDARI karena intensitas kegiatan pengajiannya di beberapa masjid kampung dan kota Pangkalpinang, terlebih karena kekayaannya melebihi tokoh-tokoh agama umumnya.

Ja'far ADDARI juga dikenal sebagai tokoh yang sangat akademis. Hal ini terlihat dari kecintaannya terhadap buku. Setiap waktu ia selalu memamfaatkan waktunya untuk membaca dan menulis.Apa yang disampaikan secara lisan pasti ada rangkuman dan konsepnya serta dibagikan kepada murid-muridnya. Beberapa kitab tentang beberapa disiplin ilmu agama merupakan hasil rangkuman catannya sehari-hari. ${ }^{13}$ Selain itu, sang kyai juga pintar beretorika. Kecerdasannya dalam beretorika juga diakui masyarakat terutama dalam menjawab pertanyaan-pertanyaan yang sulit, memecahkan permasalahan antar warga dalam masalah agama tanpa merugikan atau mempermalukan salah satu pihak.

12 Wawancara dengan Ust. Abdus Shomad di kediamannya Desa Airgegas Bangka Selatan, tgl. 10

13Wawancara dengan H. Romlan di kediaman Ust. Abdus Shomad Desa Airgegas Bangka Selatan, tgl. 11 Juni 2017 


\section{Karya-karya KH. Ja'far ADDARI}

Selain berdakwah secara lisan dan dakwah bi al-Haal, KH. Ja'far ADDARI juga menekuni metode dakwahbi al-Kitaabah (melalui tulisan), yaitu menulis kitab-kitab tentang ajaran Islam alam bahasa Arab Melayu, menulis wirid dan do'a ma'tsur, khutah Jum'at berbahasa Arab Melayu, ceramah agama yang berkenaan dengan hari besar Islam dalam Arab Melayu. Tulisan Arab Melayu lebih diutamakan atau dipilih dibandingkan dengan huruf latin, karena wibawa atau memiliki nuansa tersendiri bagi kalangan tertentu. Penghormatan masyarakat terhadai tulisan Arab Melayu lebih besar daripada hasil karya lain. Masyarakat tidak berani membungkus cabe, terasi, dan lain-lain menggunakan kertas yang bertuliskan Arab Melayu. Hal tersebut berbeda jauh dengan huruf latin yang mungkin di dunia barat lebih awal kemunculannya.

Karya-karyadalam bentuk kitab adalah: kitab Tauhid (Nurul Yaqin fii Ushuluddin), Kitab Fiqh (Sabililul Muttaqien) yang terdiri dari; (KitabThaharah, KitabSholat, Kitab Sunnah-Sunnah dalam Sholat, Kitab Zakat, Kitab Haji), Kitab Nikah, Kitab Jenazah, Kitab Muamalah, Kitab Tasawuf, Kitab Do'a-do'a Manqul (yang terulis) dalam hadits Rasulullah saw, khutbah Jum'at dalam bahasa Arab Melayu, ceramah hari besar Islam dalam Arab Melayu dan beberapa penjelasan tentang ilmu faroid.

Saat ini, beberapa kitab hasil karya KH. Ja'far ADDARI telah dialihbahasakan oleh Amir Syuhada dan dua orang murid beliau yaitu Abdussomad dan H. Romlan ke bahasa latin Melayu sesuai dengan ejaan Arab Melayu dan sesuai dengan metode penulisan (Tanya jawab). Kitab-kitab tersebut adalah kitab tauhid (Nurul Yaqin fii Ushuluddin), Kitab Fiqh (Sabililul Muttaqien) yang terdiri dari; (KitabThaharah, KitabSholat, Kitab SunnahSunnah dalam Sholat, Kitab Zakat, Kitab Haji). Dan yang sudah dicetak dan disebarkan ke masyarakat adalah kitab fiqh (Sabililul Muttaqien) pada tahun 2017.

Kitab-kitab hasil karyanya hingga saat ini masih diajarkan di kalangan masyarakat oleh murid-muridnya yang sudah mendapat ijazah. Dan juga ajaran-ajaran keislaman yang ditulis juga dipraktekkan dalam kehidupan sehari-hari masyarakat. Masyarakat yakin dengan ilmu-ilmu agama yang sang guru ajarkan, karena semua karya tersebut bersumber dari al-Quran dan hadist shahih. Masyarakat Airgegas merupakan tipe 
Mawa'izh

Jurnal Dakwah dan Pengembangan Sosial Kemanusiaan

Vol. 9, no. 2 (2018), pp. 18-25.

masyarakat yang sulit percaya dengan ajaran dan pendapat orang lain, namun bila sudah percaya, mereka terus percaya dan berpegang teguh kepada hal tersebut. ${ }^{14}$

\section{KH.Ja'far ADDARI, Bukan Sekedar Da'i}

Ketika kyai umumnya terfokus pada kegiatan-kegiatan keagamaan, tidak demikian bagi KH Ja'far ADDARI. Sang guru memikirkan masa depan dirinya dan orang lain sehingga harus berbisnis. Dalam hal ini disimpulkan bahwa sosok Ja'far ADDARI sangat ulet dan tekun. Diantaranya ia sangat menekuni dunia bisnis sebagai pembeli getah karet dari Airgegas sampai pulau besar. Agar benar-benar bertahan dan untuk kepentingan dakwah Islam di Airgegas dan sekitarnya, Ja'far ADDARI merambah ke bidang perdagangan dengan membuka toko kelontong di depan rumah-menyediakan barangbarang kebutuhan pokok masyarakat dan juga menekuni jual beli hasil kebun seperti karet dan lada. Tak ketinggalan kyai juga memiliki beberapa lahan kebun sebagaimana diurai sebelumnya. Saat itu umumnya penduduk di Desa Airgegas juga berkebun lada dan karet.

Tanpa disadari dan karena begitu kuatnya rasa penghormatan murid kepada sang guru, tidak sedikit anak-anak didik secara suka rela membantu penanaman, perawatan dan pemanenan hasil kebun. Pola hubungan intreaktif guru-murid semacam ini berlaku hingga saat ini di beberapa pondok pesantren di Jawa. Ketulusan kyai dalam mendidik santri-santrinya memberikan pengaruh positif tersendiri dan tidak kemudian serta merta dirasionalisasikan oleh pihak luar pesantren.

Sebagaimana Rasulullah, KH Ja'far ADDARI sangat menekuni pekerjaannya baik sebagai da'i maupun pengusaha. Kesibukan dalam dunia usaha tidak menghalanginya untuk memikirkan masalah-masalah sosial kemasyarakatan; pengajaran, konsultasi agama, pengajian dan lain-lain. Sebagai seorang pengusaha, kyai tergolong sukses. Namun demikian dalam kehidupannya, ia tidak berlebihan dalam mencintai harta duniawi. Zakat, infaq, sadakah dan wakaf tetap beliau keluarkan sesuai dengan syariat Islam. ${ }^{15}$

\footnotetext{
14 Wawancara dengan Ust. Abdussomad di kediamannya Desa Airgegas Bangka Selatan, tgl. 11 Juni 2017

15 Wawancara dengan H. Romlan di Pondok Pesantren Darul Istiqomah Airgegas Bangka Selatan, tanggal 2 April 2017.
} 


\section{Pemikiran Keislaman KH.Ja'far ADDARI}

Seorang tokoh atau ulama tidak hanya dinilai kualitas dirinya dari apa yang ia sampaikan dalam bentuk perkataan/ lisan dan juga sikap yang ia tampilkan terhadap orang lain. Terkadang kita terlalu cepat mengagumi seseorang dari hal-hal tertentu yang sebenarnya sangat simbolik dilekatkan pada dirinya. Tak kalah pentingnya adalah pemikiran yang bersumber dari diri pribadi orang-orang tertentu, disebut wujud ideal yang membedakan kemudian seseorang dengan orang lain.

Tidak banyak orang yang memiliki ide, gagasan, pemikiran apalagi konsep, teori atau ideologi tertentu yang kemudian mendapat pengakuan dan apresiasi dari orang kain. Kalaulah ada, kenyataannya tidak berlangsung lama karena dipaksakan dan atau digagas penyampaiannya untuk tujuan tertentu. Tokoh atau ulama juga belum pasti memiliki pemikiran cemerlang kecuali pribadi-pribadi tertentu di zamannya dari dulu hingga saat ini. KH.Ja'far ADDARI adalah ulama di Pulau Bangka yang tidak hanya berceramah dalam dakwahnya, melainkan menulis. Ia memiliki pemikiran keislaman yang kuat. Hal tersebut tampak dari beberapa kitab karyanya yang hingga saat ini masih dipergunakan oleh beberapa muridnya, baik dalam pengajian rutin keagamaan di rumah dan masjid, madrasah maupun pondok pesantren.

Berikut ini diuraikan pemikiran tokoh tersebut dalam beberapa bidang tertentu.

\section{a. Tauhid/Aqidah}

Akidah merupakan hal yang paling mendasar dalam beragama, disebut,"ushul alDiin" atau 'Aqaa'id al-diin, selanjutnya bernama ilmu tauhid atau al-Fiqh al-Akbar. Setelah itu meningkat menjadi ilmu kalam (Teologi Islam). Secara objektif ilmu kalam sepadan dengan ilmu tauhid, karena keduanya membahas tentang keesaan Allah. Hanya saja pembahasan ilmu kalam lebih kepada argumentasi penguasaan logika, dan dalam perkembangannya para ahli atau ulama teologi cenderung membedakan kedua ilmu tersebut. ${ }^{16}$ Beberapa ahli menegaskan tentang definisi Ilmu Kalam, yaitu: pertama, disiplin ilmu yang membahas tentang Dzat dan sifat Allah serta hal-hal yang mumkinat, mulai dari yang berkenaan dengan masalah dunia sampai kepada masalah pasca kematian berdasarkan doktrin Islam; kedua, sebuah disiplin ilmu yang meliputi

16 Rusydi Sulaiman, Ilmu Kalam: Substansi, Sejarah Kemunculan dan Bnetuk-Bentuk Aliran Kalam, dalam Academia, Jurnal Pemikiran, Pendidikan dan Kebudayaan Islam, Vol.2, Nomor.2, September 2007 , Lembaga Penelitian IAI Nurul Jadid Probolinggo, ,h. 58 
berbagai argumentasi tentang akidah (iman) yang diperkuat dengan dalil-dalil yang rasional; ketiga, sebuah disiplin ilmu yang berkenaan dengan akidah (iman) ini didukung oleh argumen-argumen rasional atau berdasarkan nalar manusia yang dapat diterima orang (bersifat positif rasional). ${ }^{17}$

Pemikiran Ja'far ADDARI tentang akidah secara tidak langsung tercerminkan dalam kitabnya, yaitu "Nurul Yaqin fii Ushuluddin".Artinya cahaya yang diyakini dalam Ushuludin. Kitab yang ditulis dengan Arab Melayu ini membahas tentang sifatsifat Allah, swt., yaitu duapuluh sifat wajib, duapuluh mustahil dan sifat jaiz. Adapun metode yang digunakan dalam penyajian kitab tersebut adalah metode tanya jawab. Metode ini digunakan untuk memberikan kemudahan bagi para pembaca dalam memahami dan mengambil intisari setiap materi pembahasan dalam. Nampaknya bagi masyarakat kebanyakan, metode ini sangat sesuai bagi mereka apalagi bahasa Arab Melayu saat itu lebih familiar dengan dialog keseharian penduduk setempat. Dan hampir semua kitab atau naskah bahan pelajaran ilmu-ilmu dasar agama oleh ulama lainnya di Bangka tertulis dalam Arab Melayu. Dalam tradisi ilmiah sebelumnya, ulama tertentu megalihkan bahasa materi pelajaran yang diajarkannya kedalam bahsa kaumnya, seperti Arab Jawa, Arab Madura termasuk Arab Melayu. Hal tersebut dilakukan agar mudah dicerna oleh para murid.

Kitab ini diajarkan secara sorogan, yaitu para murid berkumpul di suatu tempat kemudian sang guru menjelaskan materi yang disampaikan sesuai dengan isi kitab yang ada. ${ }^{18}$ Kitab tauhid ini langsung beliau tulis dengan tangan sendiri kemudian para murid biasanya menggandakannya dan membawa setiap waktu pengajaran.

Adapun muatan ilmu tauhid yang diajarkan oleh KH.Ja'far ADDARI tidak juga berbeda dari materi guru-guru lainnya sesuai dengan apa yang telah didapatkan dan dipahami selama menuntut ilmu, yaitu pembahasan tentang sifat wajib, mustahil dan jaiz. Pemikiran tauhid Ja'far ADDARI cukup mendalam berkenaan dengan sifat-sifat tersebut. Oleh karena itu, pelajaran tentang sifat-sifat ini menjadi hal yang mutlak

${ }^{17}$ Sulaiman, Ilmu Kalam, h. 59

${ }^{18}$ Dua metode pembelajaran lainnya adalah wetonan atau bandongan. Wetonan adalah metode pengajaran dengan cara ustadz/kiai membaca, menerjemahkan, menerangkan dan mengulas kitab/bukubuku keislaman dalam bahasa arab, sedangkan santri mendengarkannya. Mereka memperhatikan kitab/bukunya sendiri dan membuat catatan-catatan (baik arti maupun keterangan) tentang kata-kata yang diutarakan oleh ustadz/kiai. Syamsul Nizar, Sejarah Pendidikan Islam : Menelusuri Jejak Sejarah Pendidikan Era Rasulullah sampai Indonesia, cet ke-2, (Jakarta: Pranada media 2008). Hlm, 286 
untuk diajarkan pertama kali dalam memahami ilmu tauhid. Lagi pula di Bangka, aspek tauhid (akidah, ushuluddin) menduduki kedudukan yang paling penting bagi komunitas muslim tradisional. Sifat duapuluh dan kegiatan mempelajarinya disebut, mengaji tauhid atau mengaji sifat duapuluh. Ia kemudian menjadi ukuran pengetahuan agama seseorang. Hal tersebut menjadi persyaratan penting bagi seseorang untuk mendapatkan gelar ulama, disebut Guru atauTuan Guru. ${ }^{19}$

Prinsip keber-Islam-an KH. Ja'far ADDARI adalah ma'rifatullah (mengenal Allah Swt) adalah hal yang wajib dipahami oleh seorang muslim sebelum ia menjalankan perintah-perintah-Nya. Mengapa harus ma'rifatullah dulu baru melakukan perintahNya dan menjauhi larangan-Nya? Dalam konsep ketauhidan tokoh tersebut, bahwa tidak sah ibadah seseorang sebelum mengenal Allah Swt. Logikanya, bagaimana bisa menjalankan perintah dan menjauhi larangan dengan baik jikalau seseorang kemudian tidak mengenal siapa yang memerintah dan melarang. Ma'rifatullah dimaksud bukan sesuatu yang ditempuh para sufi dalam konteks ilmu Tasawuf.

Pengertian ma'rifatullah dalam konsep ketauhidan Ja'far ADDARI adalah mengenal Allah SWT dengan segala sifatnya yang wajib, yang mustahil, yang ja iz bagiNya dengan i'tiqod (keyakinan) yang jazam (tidak bisa diganggu gugat kebenarannya) yang mufaqoh (yang disepakati) dengan hak dan dalil. Mengenal tidak sebatas mengetahui, melainkan juga meyakini dan merasakan kebesaran Allah sebagai Dzat Yang Maha Esa dan Yang memiliki segala kemutlakan diatas manusia.

Menurutnya, ma'rifatullah harus didasari oleh I'tiqod atau keyakinan yang kuat, disebut dengan iman. Sebagaimana pengertian iman yang dijelaskan dalam kitab tersebut, yaitu membenarkan dengan hati akan apa yang dikenal dan diiqrorkan (diucapkan) dengan lisan serta diamalkan dengan jawarih (anggota). Orang yang sudah beriman (mukmin), diberi pahala pada hari akhir dan ditempatkan di dalam surga-Nya. Sedangkan orang yang tidak beriman (kafir) sebaliknya mendapat dosa pada hari akhir dan mereka kemudian ditempatkan dalam neraka. Adapun orang yang beriman dengan mulut tidak dengan hati dinamakan munafik. Mereka termasuk golongan kafir yang pasti dijerumuskan ke api neraka.

19Zulkifli, Kontinuitas Islam Tradisional di Bangka, (Bangka: Siddiq Press, 2007), 32 
Konsep ma'rifatulah KH.Ja'far ADDARI tercerminkan dalam 20 sifat wajib, 20 sifat mustahil dan 1 sifat jaiz. Pada hakekatnya Allah Swt memiliki banyak sifat namun 20 sifat wajib itu sudah cukup untuk diketahui.

\section{b. Akhlak}

Selain disipilin ilmu tauhid atau aqidah, KH. Ja'far ADDARI juga mendalami disiplin ilmu akhlak. Hal tersebut terbukti bahwa ia juga telah banyak menulis beberapa naskah perihal tersebut. Menurutnya, bahwa Akhlak menyangkut penguatan hubungan manusia dengan makhluk lainnya. Bila hubungannya dengan penguatan kedekatan dengan Dzat Yang Menciptakan, disiplin ilmu tersebut disebut tasawuf, kelanjutan dari akhlak dimaksud. ${ }^{20}$ Sebaiknya ilmu tasawuf tidak disentuh terlebih dahulu sebelum mempelajari ilmu akhlak, karena akhlak merupakan dasar bagi setiap manusia untuk berpijak.

Pemikiran keislaman tentang akhlaq dapat dilihat dari dari kitab nya yang berjudul, "Tasawwuf". Kitab tersebut ditulis dengan Arab Melayu yang lebih banyak membahas tentang kesucian bathin dan cara menyucikan hati, serta perkaraperkara yang dapat merusak bathin. ${ }^{21}$ Tasawuf adalah ilmu yang mempelajari bagaimana seseorang mendekatkan diri dengan Tuhannya, sedangkan akhlak merupakan bentuk penguatan sikap antar sesama manusia.

Tidak sebatas penguasaan teoritik keilmuan akhlak dan tasawuf, bahwa ulama yang bernama Ja'far ADDARI juga mengimplementasikannya dalam kehidupan sehari-hari sebagai pribadi dan juga sebagian sosial dari masyarakat. Tokoh tersebut beliau selalu menjaga lisan dari perkataan-perkataan kotor dan yang menyakitkan. Bahkan kepada orang yang bermaksiatpun, ia tetap menjaga tutur kata agar tidak menyakiti orang tersebut.

Sebagai tahapan lanjutan dari ilmu akhlak, tasawuf juga disentuhkan oleh KH.Ja'far AD-DARI kepada murid-murid tertentu. Setidaknya aspek tersebut tercermin dari keperibadiannya sehari-hari. Walaupun sang guru sangat kaya dan tekun berbisnis, ia tidak selalu menampakkan kesederhanaan sikapnya dan sangat tawadhu' sebagaimana yang melekat pada para sufi sebelumnya dalam sejarah Islam. Menurutnya, tasawuf merupakan ilmu kebathinan yang harus diketahui oleh 
setia muslim. Pastinya setelah akhlaknya baik. Bila difilosofikan, bahwa ilmu tauhid ibarat urat dari sebatang pohon, dan ilmu fiqh merupakan ranting dan buah dari itu. Sedangkan ilmu tasawuf adalah tanah dan air dari pohon tersebut. Tanpa dukungan ilmu tasawuf, yang dua lainnya tidak akan berarti bagi kehidupan manusia. Oleh karena itu ulama ini menyimpulkan bahwa hukum mempelajarinya adalah fardhu 'ain. ${ }^{22}$ Corak tasawuf yang diajarkan oleh guru tersebut adalah tasawuf akhlaki sebagaimana yang dilekatkan kepada al-ghazali.

Pokok-pokok ajaran tasawuf akhlaki-nya nya adalah tazkiyah an-Nafsi atau pensucian hati. Terdapat beberapa amalan dalam mensucikan hati, yaitu: sabar, syukur, ikhlas, siddik, mahabbah, tawakkal, taubah,khauf dan zuhud. Setiap sufi memiliki konsep tahapan pensucian diri yang disebut maqam-maqamat. Dan yang lainnya adalah hal-ahwal. Yang pertama dimaknai sebagai semangat yang dilakukan seseorang dalam mendekatkan dirinya kepada Allh. Adapun hal dimaknai sebagai perolehan dari Allah karena kebaikan dan kebajikan diri seseorang. ${ }^{23}$ KH.Ja'far ADDari disamping secara teoritik memaparkan keilmuan tasawuf, ia juga mengamalkannya dan tersentuh secara perlahan kepada murid-murid dekatnya.

\section{c. Hukum Islam dan Syariah}

Hukum Islam merupakan bagian dari keseluruhan Islam itu sendiri. Adapun sumber utama Hukum Islam adalah al-Qur'an, dan yang kedua, al-Hadits, Sunnah Nabi Muhammad,SAW. Keduanya disebut sebagai sumber syari'ah Islam, karena bersifat tetap (tsabaat) dan keberadaannya kully (universal), serta tingkat kebenarannya bersifat mutlak (qhat'iy). Sifat lain yang melekat kepadanya, abadi (mempunyai daya hidup sepanjang masa). Yang terpenting dalam kajian syari'ah adalah mengetahui rahasia (Asraar al-Syari'ah) dan hikmah penetapan hukum untuk kemaslahatan umat. ${ }^{24}$

KH. Ja'far ADDARI merupakan salah satu ulama Bangka yang memiliki semangat dakwah tinggi dalam memahamkan Islam kepada masyarakat Bangka.

\footnotetext{
22 Wawancara dengan Ust. Abdus Shomad di kediamannya Desa Airgegas Bangka Selatan, 22 Mei 2017

${ }^{23}$ Sulaiman, Pengantar Studi Tasawuf,h.23-24

${ }^{24}$ Sulaiman, Orientasi HUKUM Islam, dalam, Yasan Matzen, Menuju kesempurnaan Ibadah, (Jakrta: Pustaka Fahema, 2017),h. xiii
} 
Dengan bekal ilmu agama yang didapatkan di Darul Ulum Mekkah selama 13 tahun, beliau tidak hanya berdakwah dengan lisan, namun juga tulisan dan bilhal (Tingkah laku dan Perbuatan). Dalam menekuni dakwah dengan tulisan, beliau menghasilkan beberapa karya tulis tentang ajaran-ajaran agama Islam sebagaimana telah diurai tertulis dalam Arab Melayu. Salah satu karya beliau adalah kitab fiqh yang diberi judul Sabilul Muttaqin yang berarti jalan bagi orang-orang yang bertaqwa.

Salah satu indikator untuk mengetahui kedalaman pemikiran fiqh seseorang dapat dilihat dari beberapa karya miliknya. Begitu juga KH.Ja'farADDARI adalah ulama di Bangka yang juga menghasilkan beberapa kitab, diantaranya adalah Kitab fiqih Sabilul Muhtadin. Kitab Fiqh tersebut aslinya ditulis dalam bahasa Arab Melayu. Namun demikian, seiring perjalanan waktu dan lemahnya kemampuan masyarakat dalam membaca tulisan Arab Melayu, maka buku fiqh tersebut dikonversikan ke dalam bahasa Indonesia Melayu tanpa merubah sedikitpun metode penulisannya.

Adapun metode yang digunakan adalah tanya jawab. Bagi masyarakat awam metode ini sangat tepat untuk mempelajari dasar-dasar syariah agama Islam. Apalagi ajaran-ajaran syariah yang tertulis dalam buku fiqh ini sesuai dengan mazhab yang dipegang oleh mayoritas masyarakat Bangka yaitu mazhab Syafi'i. Artinya pemikiran dalam buku tersebut sangat situasional dan psikologis bagi mereka sehingga kemudian mudah dicerna dan kemudian diamalkan dalam kehidupan sehari-hari.

Paparan penulis dalam buku fiqh tersebut menunjukkan bahwa Kefashihannya dalam bahasa Arab dan pemahaman yang mendalam tentang mazhab Syafi'I, beberapa kitab yang berafiliasi ke mazhab Syafi'I dijadikannya sebagai bahan rujukan utama dalam penulisan buku fiqh ini seperti kitab 'Ianatu ath-tholibin. ${ }^{25}$

Pada dasarnya mazhab fiqh yang beliau anut dalam memahami syariat Islam adalah Syafi'i, sambil menyesuaikan masalah tertentu dengan kondisi sosial setempat. Setiap materi yang diajarkan terurai satu persatu berdasarkan

25 Dja'far ADDARI, Kitab Fiqh Sabilul Muhtadin, Terj. Amir Syuhada, (Jakarta: Pustaka Fahema, 2017),h. iii 
pertanyaan yang dikemukakan oleh beberapa murid sebelumnya. Adapun potongan Hadits Nabi dan ayat al-Qur'an ikut menyempurnakan penjelasan tersebut.

\section{Gerakan Dakwah KH. Ja'far ADDARI dan Pengaruhnya terhadap Perubahan} Sosial Masyarakat

Sebagai seorang fiqur dan tokoh masyarakat, disimpulkan bahwa KH Ja'far ADDARI memiliki banyak pemikiran yang berkenaan dengan kemaslahatan masyarakat. Ada yang sudah terwujud dan adapula yang belum bahkan tidak terwujud sama sekali.

Adapun pemikiran-pemikirannya dalam meningkatkan kualitas iman adalah; pertama, membasmi praktek kesyikiran, diantaranya penghapusan ritual Hikok Helawang di Airgegas. Acara ini adalah adat tahunan masyarakat dengan membawa ayam panggang ke Masjid bersama nasi ketan kemudian ayam dikantet (disobek) setelah itu dibawa pulang ke rumah. Kegiatan ini bertujuan untuk melepas bala, murah rezeki, terhindar dari makhluk jahat. ${ }^{26}$ Untuk memahami kegiatan Hikok Helawang, Kyai mengikuti kegiatan ini selama 4 tahun; memasak tiga ekor ayam, satu untuk anak, satu untuk tamu, dan satu untuk dibawa ke masjid. Setelah meyakini bahwa kegiatan ini benarbenar telah terjadi penyimpangan syari'ah, baru ditutup. Lambat laun adat tersebut terkikis dan tidak dipraktikkan oleh masyarakat Airgegas.

Tonggak kebangkitan Islam di Airgegas dimulia setelah penghapusan hikok helawang sekitar tahun 1970.27 Setelah itu, masjid semakin ramai dan semangat beribadah meningkat kemudian pada tahun 1986 masjid penuh kemudian membuat masjid yang lebih besar. Setelah masyarakat Airgegas menghentikan acara Hikok Helawang masyarakat Delas, Bencah, dan Nangka pun ikut menghapus ritual ini.

Selain menghapus ritual Hikok Helawang, dalam masalah aqidah beliau juga mengikis kepercayaan masyarakat kepada kebiasaan bayar niat. Bayar niat merupakan ritual pemotongan ayam di hutan dengan disaksikan oleh seorang dukun; ada yang memotong 400 ekor ayam. Sang guru juga membimbing masyarakat untuk tidak pergi ke dukun apabila terkena penyakit. Ia selalu menganjurkan untuk berobat ke dokter dan tidak ke dukun tertentu. ${ }^{28}$

${ }^{26}$ Wawancara dengan H.Julaili di kediamannya Desa Bencah Bangka Selatan, tgl 17 Juni 2017

27 Wawancara dengan Ust. Abdussomad di kediamannya Desa Airgegas Bangka Selatan tgl 17 Juli 
Kedua, mendirikan Kelompok Pengurus Kematian yang tugasnya menarik sumbangan kematian kepada seluruh masyarakat, kemudian menyerahkan kepada keluarga yang ditinggal mati. Kebiasaan masyarakat dulu, sebelum mayat dikubur orang bini (wanita) memasak untuk disuguhkan kepada para pelayat dan pengantar jenazah sekembalinya dari kuburan. Pada malam ketiga dan ketujuh makan nasi dan malam pertama, kedua, keempat, kelima, dan keenam makan selain nasi-cukup banyak biaya yang dikeluarkan oleh keluarga yang ditinggal mati anggotanya.

Ketiga, mendirikan Persatuan Tarbiyatu Jami'atul Muhajirin di Semabung. Persatuan ini bertujuan untuk menaungi dan mengayomi orang-orang kampung yang belajar di kota dan juga mempererat tali silaturrahim antar sesama mereka. Kegiatan yang diadakan dalam persatuan ini adalah pengajian tentang ajaran-ajaran agama.

Keempat, mendirikan Madrasah di Airgegas. Tujuan pendiriannya untuk mengajari anak-anak tentang baca tulis al-quran dan ilmu-ilmu keislaman lainnya. Madrasah ini terletak di tanah miliknya, namun proses pembelajaran hanya berjalan 2 tahun.

Kelima, mendirikan Pondok Pesantren al-Fatah tahun 1972. Tanah, pengajar dan sistem pendidikan sudah siap, akan tetapi tidak disetujui (tidak ditanda tangani) oleh pihak pemerintah sehingga terhambat dan tidak bisa berdiri. Pemikiranini diteruskan oleh murid-murid yang bekerjasama dengan beberapa alumni Pondok Modern Gontor dan sekitarnya sehingga Pondok Pesantren yang dicita-citakan berdiri pada tahun 2010, bernama Pondok Modern Darul Istiqomah. Putra-putri Airgegas dan sekitarnya akhirnya dapat menempuh studi di pesantren tersebut. Sudah pasti idealisme pembentukan lembaga pendidikan semacam pesantren memberi pengaruh positi bagi dinamika pearadaban Islam di Pulau Bangka.

\section{Kesimpulan}

Berdasarkan penelusuran peneliti tentang ketokohan KH Ja'far ADDARI -- seorang ulama yang lahir di Delas eksodus ke Airgegas dan menyebarkan dakwah Islam di daerah tersebut-- disimpulkan bahwa ulama tersebut merupakan sosok pribadi yang sangat kuat, memiliki integritas dan sentuhan kepribadiannya benar-benar menyentuh masyarakat sekitarnya. Tokoh tersebut berbeda dengan tokoh-tokoh lain umumnya di pulau Bangka, karena ia tidak hanya memiliki kompetensi lisan dalam bentuk ceramah 
dan khutbah melainkan memiliki kecakapan tulisan, sikap sangat tawadhu', memiliki karisma dan lebih lanjut memiliki pemikiran yang sangat kuat melebihi tokoh-tokoh lain.

Ja'far ADDARI selain dari satu dua tokoh lainnya merupakan ulama yang juga menempuh pendidikan di usia sangat remaja ke kota Mekkah bermukim 13 tahun mendalami ilmu-ilmu agama di sebuah perguruan tinggi bernama Darul Ulum, berguru kepada beberapa ulama penting di timur Tengah kala itu. Selanjutnya ia memberikan kontribusi pemikirannya terhadap masyarakat di Bangka Selatan tepatnya di desa Airgegas. Dan kemudian melanjutkan dakwahnya di Pangkalpinang. Ja'far ADDARI sangat diminati oleh masyarakat terbukti dari beberapa forum pengajian yang digagasnya dan bahkan masih berlangsung sampai saat ini. Tokoh ini melahirkan sejumlah murid yang cukup berhasil di tengah masyarakat. sebagian mengelola masjid sebagai central keagamaan, sebagian lain mengelola madrasah dan Pondok Pesantren bahkan beberapa di antara mereka ada yang memiliki peran penting di jabatan pemerintahan seperti Kementrian agama dan jabatan sosial politik lainnya di tengah masyarakat.

Satu hal yang membedakan ulama ini dengn tokoh-tokoh lain umumnya di Bangka, bahwa ia memiliki kompetensi menulis, terbukti terdapat beberapa kitab karyanya yang dipergunakan di beberapa daerah sekitar. Kemudian pemikiran-pemikiran Ja'far ADDARI secara keseluruhan meliputi ilmu-ilmu dasar dalam Islam, yaitu tauhid/akidah, hukum Islam dan akhlak. Kemudian kita-kitab yang ditulis oleh ulama tersebut sangat mudah dicerna oleh masyarakat karena metode penyajian yang sangat lugas. Misalnya dalam fiqh Sabilul Muthtadin, Ja'far ADDARI menerapkan metode tanya jawab untuk mempermudah pemahaman para murid. Ja'far ADDARI adalah tokoh yang tidak berhenti menulis sekalipun di toko. Semestinya melayani konsumen namun ia juga sempatkan waktu untuk membaca.

Selain itu, Ja'far ADDARI juga dikenal dengan ulama yang tidak hanya identik dengan kajian-kajian keagamaan, melainkan juga menggerakan masyarakat melakukan pemurnian ajaran agama; merubah tradisi-tradisi lama. Masyarakat yang mulanya sangat yakin dengan keyakinan dan tradisi sebelumnya kemudian bergeser ke hal-hal yang baru berkat gerakan dan semangat pembaharuan yang dilakukan oleh Ja'far ADDARI. Ia adalah sosok yang sangat mandiri dan tidak menggantungkan hidupnya kepada orang lain. Di samping berwirausaha, berkebun, berdagang, ia juga memberdayakan ekonomi masyarakat sekitarnya. Murid-muridnya tidak hanya diajarkan ilmu-ilmu agama namun 
juga dibekalkan kepada mereka semangat kewirausahaan. Menurutnya, kelansungan hidup seseorang tidak boleh tergantung kepada orang lain. Kyai sekalipun juga harus mandiri dari segi ekonomi dan bahkan kaya.

Tidak dipungkiri bahwa ketokohan Ja'far ADDARI sangat memberi pengaruh yang sangat positif bagi masyarakat di sekitarnya bahkan Pangkalpinang. Munculnya beberapa masjid dengan sejumlah rutinitas pengajian-pengajian kitab, intensitas pembelajaran agama melalui madrasah dan Pondok Pesantren dan juga kewirausahana merupakan bukti kebesaran tokoh tersebut. Ja'far ADDARI adalah tokoh yang sangat vokal, namum memiliki pengetahuan dan wawasan keorganisasian yang sangat luas. Ia juga membangun hubungan pribadi dan sosial ke semua pihak. 


\section{DAFTAR PUSTAKA}

Dja'far ADDARI, Kitab Tasawwuf, ( Bangka: belum diterbitkan)

Dja'far ADDARI, Kitab Fiqh Sabilul Muhtadin, Terj. Amir Syuhada, (Jakarta: Pustaka Fahema, 2017)

Rusydi Sulaiman, Ilmu Kalam: Substansi, Sejarah Kemunculan dan Bnetuk-Bentuk Aliran Kalam, dalam Academia, Jurnal Pemikiran, Pendidikan dan Kebudayaan Islam, Vol.2, Nomor.2, September 2007 , Lembaga Penelitian IAI Nurul Jadid Probolinggo

Rusydi Sulaiman, Orientasi HUKUM Islam, dalam, Yasan Matzen, Menuju kesempurnaan Ibadah, (Jakarta: Pustaka Fahema, 2017)

Syamsul Nizar, Sejarah Pendidikan Islam : Menelusuri Jejak Sejarah Pendidikan Era Rasulullah sampai Indonesia, cet ke-2, (Jakarta: Pranada media 2008)

Syaifa Auliya Akhidati, Kyai dan Perubahan Institusi Sosial, (Yogyakarta: Pustaka Pelajar, 2015)

Zamakhsyari Dhofier, Tradisi Pesantren: Studi tentang Pandangan Hidup Kyai,(Jakarta: LP3ES, 1982)

Zulkifli, Kontinuitas Islam Tradisional di Bangka, (Bangka: Siddiq Press, 2007) 